\title{
1.アポリポプロテイン (a)
}

\author{
一瀬 白帝
}

山形大学医学部分子病態学講座

Key words : 高 $L p(a)$ 血症，遺伝的多型性，クリングル 4, 抗線溶作用，TGF- $\beta$

(脳卒中 $21: 437-440,1999$ )

\section{1. はじめに}

アポリポプロテイン (a) [Apo(a)]は，低密度リポプ ロテイン（LDL）に酷似したリポプロテイン（a）[Lp (a)］に含まれる高分子蛋白質で (図 1)，動脈硬化症の 独立した伦険因子である，その血中濃度は 0 150 mg $/ \mathrm{d} l$ と,個人間で 1,000 倍以上の差があることが他の血 槳蛋白質にはない特徽である。また, Apo(a)の分子量 (アイソフォーム) \& 300 $800 \mathrm{kDa}$ と個人によって差 があり，それぞれのアイソフォームも遺伝する，従っ て, 各個人の Apo(a) アイソフォームと Lp (a) 濃度は 相伴って共優性形式で遺伝する. 血中 $\mathrm{Lp}(\mathrm{a})$ 濃度が 25 $\sim 30 \mathrm{mg} / \mathrm{d} l$ を越える状態を高 $\mathrm{Lp}$ (a) 血症と呼ぶ.

Lp（a）の生理的機能については定説が無いが，少な くとも LDL と同様, 末梢に脂質を運搬する機能を持つ と思われる．また，組織損傷後の炎症反応が消褪して 組織再生が活発になる時期にApo（a）が集積するの で,組織の修復に関与していることが示唆される ${ }^{\prime}$. 今 でこそ我々は「飽食の時代 (高々ここ 40 年？)」に生き ているが，ヒトの歴史は「怪我と飢餓との戦い」であ るから，進化の上でApo(a) 遺伝子が出現したことは 生存に有利に働いたに違いない。

\section{2. $A p o(a)$ の病理作用}

Apo（a）は，血栓溶解反応の主役を演じるプラスミノ ゲンと同じ遺伝子ファミリーに属するので相同性が高

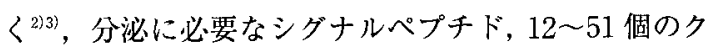
リングル 4, クリングル 5,七リン型蛋白質分解酵素样 ドメインから構成される. Lp (a) は細胞外マトリック スの蛋白質に結合・沈着するとともに，過酸化物質に 修飾されてマクロファージに摂取され，脂質を蓄積さ せて動脈硬化を促進する。また，Lp（a）はフィブリン や単球/マクロファージ, 血管内皮細胞へのプラスミノ ゲンの結合を競合的に阻害し, 局所でのプラスミン生

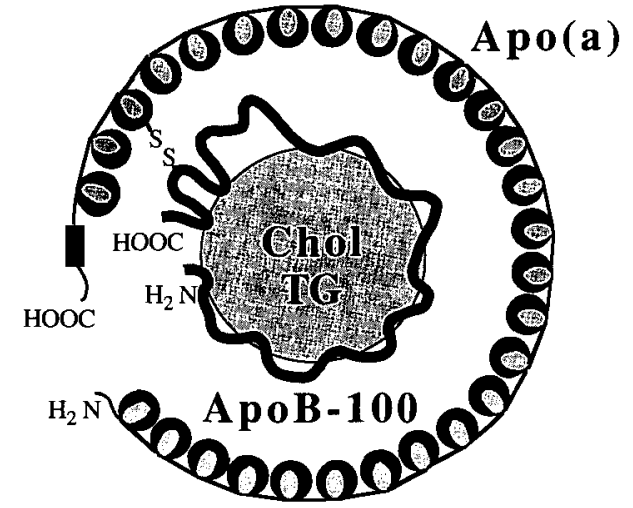

图 $1 \mathrm{Lp}(\mathrm{a})$ 粒子と Apo(a) 分子の構造 Apo (a) は各アイソフォームに応して 12〜51 個のクリ ングル 4 を持つ. 最後から 1 つ前のクリングル 4 の Cys 残基がアポ B-100のC末端側の Cys 残基と S-S 結合する、Apo（a）のC 末端側の四角はセリン型蛋白 睤分解酵素ドメインを表す. Chol；コレステロール， TG；トリグリセリド(一瀨白帝, 分子リピドロジー, 1997 より用)

成やフィブリン溶解反応を抑制するので，その抗線溶 作用が血栓形成を促進する原因となる ${ }^{4}$. 一方,プラス ミンは潜在型 TGF- $\beta$ を限定分解により活性化して平 滑筋細胞の遊走と増殖を抑制するが，Lp（a）はプラス ミン生成を阻害することによってこの反応を抑制す る. その結果, 平滑筋細胞の遊走・增殖を許し, 動脈 硬化を促進すると考えられている5).

\section{3. 高 $L p(a)$ 血症と脳血管障害}

高 $\mathrm{Lp}$ (a) 血症は, 健常者の 2 3 倍心筋梗塞を合併 L 易いことが広く認められている。また，心筋梗塞後の 冠動脈バイパスや経皮経管冠動脈形成術 (PTCA) 後の 再閒塞も起こり易い. 更に, 高 $\mathrm{Lp}(\mathrm{a})$ 血症と動脈硬化 の程度も相関していることが, 血管造影や超音波検査 


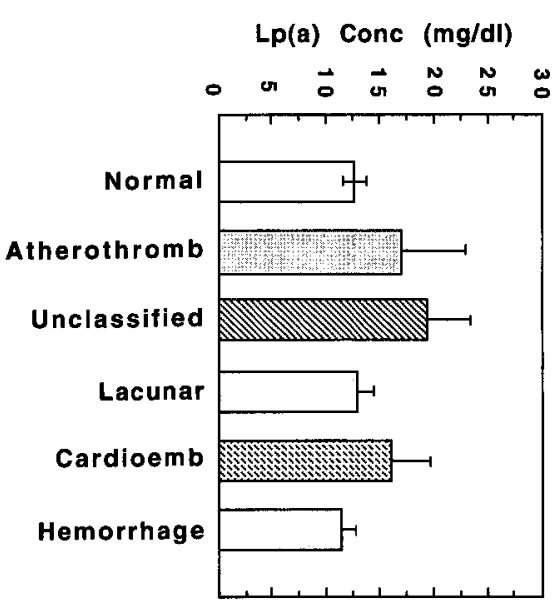

図 2 脳血管障害のタイプと Lp (a) 濃度 縦軸は酵素抗体法で測定した血中 $\mathrm{Lp}(\mathrm{a})$ 濃度である. Atherothromb ; 動脈硬化性血检性脳梗塞, Unclassified ; 分類不明, Lacunar ; ラクナ脳梗塞, Cardioemb ; 心原性塞栓性脳梗塞, Hemorrhage; 脳出血. (文献 6 より引用)

\section{によって示されている.}

一方，高 $\mathrm{Lp}$ (a) 血症と脳血管障害の相関については 異論も多い。そこで, 我々は新しい脳血管障害分類 (DR-III）に従って症例を細分して解析してみた6)。 の結果, 高 $\mathrm{Lp}(\mathrm{a})$ 血症は動脈硬化血栓夕イプや心原性 塞栓タイプに多い傾向があり, ラクナ梗塞や脳出血で は血中 $\operatorname{Lp}(\mathrm{a})$ 濃度は健常人と差が無いことを見い出し た (図 2)。また, 平均 $\mathrm{Lp}(\mathrm{a})$ 濃度は前者で正常人より 高く, 後者では同じであることも判明した. 従って, Lp（a）は動脈硬化や血栓形成に基づくタイプの脳血管 障害に相関するが，原因の異なるものとは関係が無い
と結論される.後述するように,これらの血中 $L p(a)$ 濃 度が高い症例は低分子量の Apo (a) アイソフォームを 持っていることも判明した。

\section{4. その他の血管障害と高 $L p(a)$ 血症}

次に, 脳動脈と同じ内頸動脈の末梢である網膜中心 動脈の閉塞症で $L p(a)$ 濃度を調べたところ，この疾患 では正常対照に比べて高 $\mathrm{Lp}$ (a) 血症が多いという結果 が得られだ（図 3). 臨床症状が現れていない被検者 の頸動脈の超音波断層法による解析において, 動脈硬 化性病変の有無・程度が高 Lp (a) 血症と相関している という報告もあり，高 $\mathrm{Lp}(\mathrm{a})$ 血症は頸動脈流域の動脈 硬化症を促進する危険因子であることが示唆される。

高 $\mathrm{Lp}$ (a) 血症には，その他の末梢動脈硬化性疾患も 合併し易いことが知られている．腸骨・大腿動脈領域 の閉塞性動脈硬化症（ASO）が進行すると, 間欠性跛 行, 㗒死などの虚血症状が引き起こされるので, 血中 Lp（a）濃度を測定することは臨床的に重要である．

\section{Apo（a）遗伝子の多型性と $\operatorname{Lp}(\mathrm{a})$ 濃度}

Apo（a）の分子量には個人間で大きなバリエーショ ンがありここれは Apo(a) 遺伝子のクリングル 4 を コードするエクソンの数が個人によって異なるからで ある . 血中濃度は大まかにはクリングル 4 の数に逆 相関する傾向がある. 特に分子量の大きなアイソ フォームは, 生合成時の分泌効率も低い。

$\mathrm{Apo}(\mathrm{a})$ 遺伝子の発現は, 肝臓に豊富に存在する転写 因子 Hepatocyte nuclear factor-1 $\alpha$ にってて主に制御 されている.Apo(a)の同じアイソフォームの中でも血 中レベルには相当な違いがあるので，遺伝子転写の段 階でも調節機構が存在することが予想される。そこで,

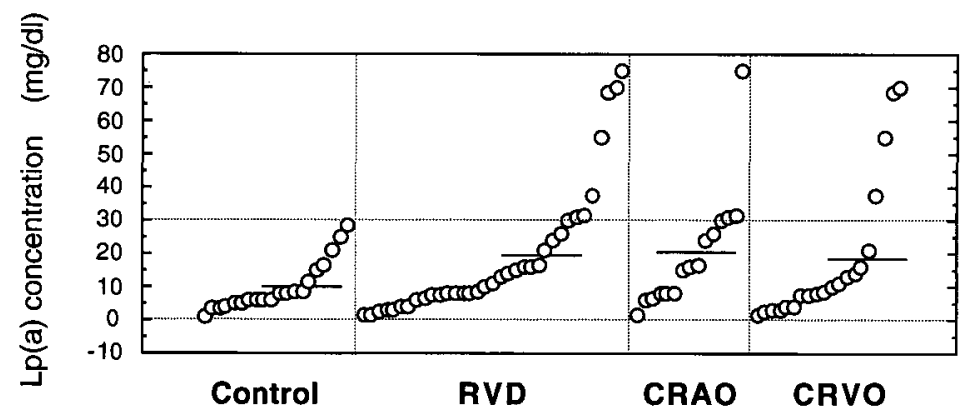

図 3 網膜血管障害のタイプと Lp (a) 濃度 縦軸は血中 $\mathrm{Lp}$ (a) 濃度. RVD; 網膜欠陷障害, CRAO; 網膜中心動脈閉塞, CRVO ; 網膜中心静脈閉塞。(文献 7 より引用) 
Apo (a) 遺伝子の $5^{\prime}$ 領域の転写開始部位周辺の塩基配 列を詳細に調べたところ，4筒所の点变異を発見し た9”。これらの内 2 箇所は何れも転写調節エレメント 自体あるいはその近傍に存在する。この領域を PCR により増幅して制限酵素 Taq I, Mae II, Bsp $1286 \mathrm{I}$ で処理すると，切断の有無で 3 箇所の塩基配列の多型 性を判定することが可能で，A〜Dの4タイプに分類 することができる。このタイプの頻度分布は人種に よって異なり，同じ日本人の間でも心筋梗塞症例では 正常人に比べてDタイプが少ない.

\section{Apo (a) 遺伝子 5' 領域の多型性}

$\mathrm{Lp}$ (a) の血中濃度は Apo（a）の生合成に依存してい

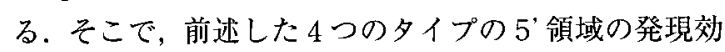
率を直接測定したところ，実際にタイプによって違い があることが証明された ${ }^{10}$. 即ち 4 つの内の最も転写 活性の高いCタイプと最も低いD タイプの間には約 3 倍の差があった. 従って,これらの塩基配列の多型性 が転写調節因子との親和性を変化させるものと考えら れる. 前述したように, 発現効率の低い Dタイプは同 ビ日本人の中でも心筋梗塞症例では正常人と較べて有 意に少ない. 従って, 心筋梗塞症例の内 $\mathrm{Lp}$ (a) 血中濃 度が高い症例の一部は，個人の Apo (a) 遺伝子の発現 効率の高さで説明される. 事実, 発現効率の高いC タイプのホモ接合体の平均 $\mathrm{Lp}$ (a) 濃度は発現効率の低 いDタイプのそれより約 3 倍高く，C，Dタイプのへ テロ接合体の $\mathrm{Lp}(\mathrm{a})$ 濃度は両者の木モ接合体の平均 $\mathrm{Lp}$ (a) 濃度のちょうど中間である.

以上のように, Lp（a）の血中濃度は Apo（a）遺伝子 $5^{*}$ 発現調節領域の塩基配列の多型性とクリングルドメ インの数の多型性によって規定されている（図 4).

\section{7. 高 $L p(a)$ 血症の治療}

他の高脂血症（高リポプロテイン血症）と同様, 単 に血中の $\mathrm{Lp}$ (a) 濃度が高いだけでは何ら臨床症状を示 さないが, 次第に動脈硬化を進展させ，比較的若年で あるにもかかわらず心筋梗塞や脳梗塞を発症させる. 従って，予防医学の立場からはまずコントロール可能 な他の危険因子を排除する努力をすることが勧められ る. 高 $\mathrm{Lp}$ (a) 血症で心筋梗塞や脳梗塞を発症した個人 には進行した動脈硬化巣が存在する可能性が高いの で, 再発を防いだり冠動脈バイパスやPTCA 後の再狭 窄を防ぐために Lp（a）低下療法を行なうべきであろ j.

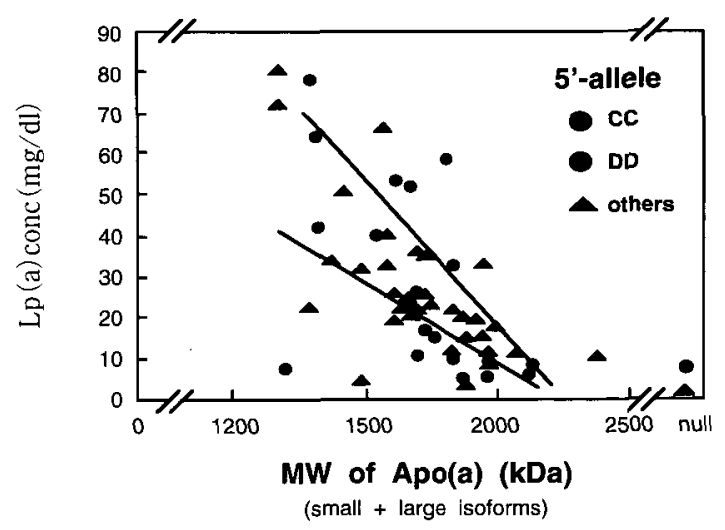

図 4 血中 $\mathrm{Lp}$ (a) 濃度, Apo (a) の分子量, 5 発現調 節領域の多型性の関係

血中 Lp (a) 濃度 (粉軸) は大まかにApo（a）の分子 量(横軸, アガロース/SDS-PAGEの後ウェスタンブ ロッティングで判定）に逆相関する. 同程度の分子 量の Apo (a) アイソフォームでも，5’発現調節領域 がCCタイプであればDD タイプより Lp (a) 濃度が 高い傾向が認められる。なお， $\operatorname{Lp}(a)$ 濃度は，2つの Apo (a) アイソフォームの内分子量の小さい胡よ り強く逆相関するが,大きい方でも逆相関するので, ここでは両者の和を用いた. (文献 10 より引用)

血中 $\mathrm{Lp}(\mathrm{a})$ 濃度を低下させる薬剤として最も一般的 なのはニコチン酸製剂である。しかし，毎日この薬郕 を大量に服用し続けるのは困難なので, 高 $\mathrm{Lp}(\mathrm{a})$ 血症 に起因寸る動脈硬化の進行や心筋梗塞や脳梗塞の発症 を予防したり，一度発症した症例での再発や冠動脈バ イパスやPTCAなどの治療の後の再狭窄を防ぐため には，より効果的な $\mathrm{Lp}(\mathrm{a})$ 低下療法を開発する必要が ある。

\section{8. おわりに}

最近，わが国においては Lp（a）に関する研究発表が 滅少傾向にあり，研究自体は一段落したかに見える. しかし， Lp (a) の生理機能や生合成過程・その制御に はまだ謎が多く，病態における血中 $\mathrm{Lp}(\mathrm{a})$ 濃度の変動 のメカニズムも不明である。これらの疑問に対する解 答が得られてこそ効果的な Lp (a) 低下療法の開発が可 能になるものと思われるので, 粘り強い基礎的, 臨床 的研究の継続が望まれる.

\section{文献}

1) Yano $Y$, Shimokawa $K$, Okada $Y$, et al : Immunolocalization of lipoprotein (a) in wounded tissues. 
Journal of Histochemistry \& Cytochemistry 45 : $559-568,1997$

2) McLean JW, Tomlinson JE, Kuang WJ, et al : cDNA sequence of human apolipoprotein (a) is homologous to plasminogen. Nature $330: 132-$ 137. 1987

3) Ichinose A : Multiple members of the plasminogen-apolipoprotein (a) gene family associated with thrombosis. Biochemistry $31: 3113-3118,1992$

4) Biemond BJ, Friederich PW, Koschinsky ML, et al: Apolipoprotein (a) attenuates endogenous fibrinolysis in the rabbit jugular vein thrombosis model in vivo. Circulation $96: 1612-1615,1997$

5) Grainger DJ, Metcalfe JC : Transforming growth factor-beta : the key to understanding lipoprotein (a) ? Current Opinion In Lipidology $6: 81-85$. 1995

6) Saito T, Ookubo R, Kuriyama M, et al : Lipoprotein (a) concentration and molecular weight of apolipoprotein (a) in patients with cerebrovascular disease and diabetes mellitus. Thrombosis Research $87: 527-538,1997$

7) Murata M, Saito T, Takahashi S, et al : Plasma lipoprotein (a) levels are high in patients with central retinal artery occlusion. Thrombosis Research $91: 169-175,1998$

8) Ichinose A : Characterization of the apolipoprotein (a) gene. Biochemical \& Biophysical Research Communications $209:$ 365--371, 1995

9) Ichinose A, Kuriyama $M$ : Detection of polymorphisms in the 5 -flanking region of the gene for apolipoprotein (a) . Biochemical \& Biophysical Research Communications 209:372-378, 1995

10) Suzuki K, Kuriyama M, Saito T, et al : Plasma lipoprotein (a) levels and expression of the apolipoprotein (a) gene are dependent on the nucleotide polymorphisms in its $5^{\prime}$-flanking region. Journal of Clinical Investigation 99 : 1361-1366, 1997

\section{Abstract \\ Apolipoprotein (a) \\ Akitada Ichinose, M.D. \\ Department of Molecular Pathological Biochemistry, Yamagata University School of Medicine}

The apolipoprotein (a) [apo (a)] gene encodes a protein component of lipoprotein (a) $[\mathrm{Lp}(\mathrm{a})]$. To study the implications of $L p(a)$, we examined plasma $L p(a)$ levels and molecular weights (MW) of apo (a) in patients with cerebrovascular disease (CVD), or central retinal artery occlusion (CRAO). Mean Lp (a) concentrations were higher in the CVD cases with atherothrombotic brain infarction than in those with brain hemorrhage and lacunar infarction. Mean Lp (a) concentrations were also significantly higher in the CRAO cases than in the controls. $\mathrm{Lp}$ (a) levels higher than $30 \mathrm{mg} / \mathrm{d} l$ were more frequent in the CRAO cases than in the controls. $\mathrm{Lp}$ (a) concentrations correlated significantly with low-MW isoforms of apo (a) in these patients. We subclassified the apo (a) gene into four types (A-D) by polymorphisms in the $5^{\prime}$-flanking region, measured plasma $\mathrm{Lp}$ (a) concentrations, and examined the expression of the gene by in vitro assay. Homozygotes of type $\mathrm{C}$ had higher $\mathrm{Lp}$ (a) levels than those of type $\mathrm{D}$ in vivo, and the relative expression of type $\mathrm{C}$ was higher than that of type $\mathrm{D}$ in vitro. Thus, $\mathrm{Lp}(\mathrm{a})$ concentrations are genetically determined by extensive polymorphisms in both the $5^{\prime}$-alleles and the numbers of Kringle 4 repeats, and hyper-Lp (a) -emia is a risk factor for thrombosis of various types of vessels.

(Jpn J Stroke $21: 437-440,1999)$

Key words: hyperlipoprotein (a) -emia, genetic heterogeneity, Kringle 4 , anti-fibrinolysis. TGF- $\beta$ 